\title{
ANALISIS PENGELOLAAN EKSTRAKURIKULER FUTSAL SEKOLAH MENENGAH ATAS SWASTA HOSANA MEDAN (Penelitian Masa Pandemi Corona Virus Desease-19)
}

\author{
Lamhot Simalango $^{1}$, Khairul Usman ${ }^{2}$ \\ 1,2 Sekolah Tinggi Olahraga dan Kesehatan Bina Guna, Indonesia \\ Jl. Aluminium Raya No. 77, Tanjung Mulia, Medan, Sumatera Utara \\ Email : lahmotsimalango@gmail.com
}

\begin{abstract}
ABSTRAK
Penelitian ini bertujuan untuk mengetahui kajian analisis yang berkaitan dengan konsep pengelolaan ekstrakurikuler dan ekstrakurikuler futsal tingkat SMA. Konsep yang digagas adalah untuk menemukan pembahasan unsur karakteristik dari konsep pengelolaan ekstrakurikuler futsal, kemudian dapat menjadi rekomendasi pada sekolah untuk menerapkan hasil kajian sebagai sarana kegiatan minat dan bakan siswa. Penelitian ini menggunakan desain penelitian deskriptif kualitatif. Desain deskriptif kualitatif diterapkan dengan melakukan analisis peneliti teori dasar. Penelitian yang dilaksanakan pada masa pandemi Corona Virus Desease 2019 (Covid-19) yakni melakukan kajian yang berkaitan dengan konsep pengelolaan ekstrakurikuler dan ekstrakurikuler futsal tingkat SMA. Data penelitian diperoleh melalui kajian analisis secara mendalam pada 3 jurnal nasional tentang konsep dan bentuk pengelolaan ekstrakurikuler, dan 3 jurnal nasional tentang kegiatan ekstrakurikuler futsal tingkat SMA. Hasil analisis kajian dapat direkomendasikan pada SMA Swasta Hosana Medan dengan menerapan sistem pengelolaan Pembentukkan sistem organisasi meliputi beberapa sistem kerja yaitu (1) Perencanaan dengan menetapkan system rekrutmen siswa dan program latihan siswa yang mengikuti ekstrakurikuler futsal; (2) Pengorganisasian dengan membentuk struktur kepengurusan yang terdiri dari ketua, sekretaris, bendahara, dan bidang yang dibutuhkan; (3) Pelaksanaan yang dilakukan dengan menjalankan program kerja yang telah dirumuskan dan memiliki pengaruh pada peningkatan prestasi siswa dan keunggulan sekolah; (4) Evaluasi yang dilakukan dengan cara menilai dan memperbaiki setiap kegiatan yang telah dilakukan sebagai dasar perencanan baru pada kegiatan atau program yang akan direncanakan kedepan; dan (5) Pengembangan merupakan hasil dari evaluasi yang bertujuan untuk meningkatan peran dan fungsi dari ektrakurikuler futsal di sekolah dengan mengikitsertakan dewan guru dan kepala sekolah sebagai dewan pembina dan pengawah. Kesimpulan terkait kajian pengelolaan ekstrakurikuler futsal, maka dapat direkomendasikan kepada Sekolah Menengah Atas (SMA) Swasta Hosana Medan untuk menerapkan sistem pengelolaan pada ekstrakurikuler futsal sebagai wujud peningkatan peran di lingkungan sekolah. Sistem pengelolaan yang telah dirumuskan terdiri dari perencanaan, pengorganisasian, pelaksanaan, evaluasi, dan pengembangan merupakan sarana melatih sekolah untuk menciptakan kemandirian siswa dalam mengelola suatu wadah belajar dan pengembangan diri.
\end{abstract}

Kata kunci: Analisis, Pengelolaan, Ekstrakurikuler, Futsal, Covid-19

\begin{abstract}
This study aims to determine the analysis related to the management concept of extracurricular and futsal extracurricular for high school level. The concept that was
\end{abstract}


initiated was to find a discussion of the characteristic elements of the futsal extracurricular management concept, then it could become a recommendation for schools to apply the results of the study as a means of student interest and activity activities. This study used a qualitative descriptive research design. Qualitative descriptive design is applied by analyzing the basic theory researchers. The research carried out during the Corona Virus Desease 2019 (Covid-19) pandemic carried out a study related to the concept of managing high school extracurricular and futsal extracurricular activities. The research data was obtained through an indepth analysis study in 3 national journals on the concept and form of extracurricular management, and 3 national journals about futsal extracurricular activities at high school level. The results of the analysis of the study can be recommended at Hosana Medan Private High School by implementing a management system. The formation of an organizational system includes several work systems, namely (1) Planning by establishing a student recruitment system and student training programs who take futsal extracurricular activities; (2) Organizing by establishing a management structure consisting of a chairman, secretary, treasurer, and required fields; (3) Implementation which is carried out by carrying out work programs that have been formulated and have an influence on improving student achievement and school excellence; (4) Evaluation is carried out by assessing and improving every activity that has been carried out as a basis for new planning of activities or programs that will be planned in the future; and (5) Development is the result of an evaluation that aims to improve the role and function of futsal extracurricular activities in schools by including the teacher board and school principal as the supervisor and supervisor. Conclusion regarding the study of futsal extracurricular management, it can be recommended to Hosana Medan Private High School (SMA) to implement a management system in futsal extracurricular activities as a form of increasing role in the school environment. The management system that has been formulated consisting of planning, organizing, implementing, evaluating, and developing is a means of training schools to create student independence in managing a forum for learning and self-development.

\section{Keywords: Analysis, Management, Extracurricular, Futsal, Covid-19}

\section{PENDAHULUAN}

Salah satu kegiatan yang dapat dilakukan dalam mewujudkan Pendidikan yang bermutu adalah kegiatan ekstrakurikuler. Peraturan Menteri Pendidikan dan Kebudayaan Republik Indonesia Nomor 62 Tahun 2014 tentang Kegiatan Ekstrakurikuler pada Pendidikan Dasar dan Pendidikan Menengah menyatakan pengembangan potensi peserta didik sebagaimana dimaksud dalam tujuan pendidikan nasional dapat diwujudkan melalui kegiatan ekstrakurikuler yang merupakan salah satu kegiatan dalam program kurikuler. Kegiatan ekstrakurikuler dapat memfasilitasi pengembangan potensi peserta didik melalui Pengembangan bakat, minat, dan kreativitas serta kemampuan berkomunikasi dan bekerja sama dengan orang lain. SMA Swasta Hosana Medan memiliki visi "terwujudnya warga sekolah yang bertaqwa, berbudaya dan berprestasi" dengan indikator visi diantaranya3 adalah: unggul dalam lomba seni, dan ketrampilan. Dalam misinya tercantum diantaranya: menyediakan wadah kegiatan siswa, menumbuhkan semangat berkompetisi dan berprestasi. Tujuan Sekolah untuk mewujudkan visi dan misinya berdasar kriteria Standar Kompetensi Lulusan (SKL) adalah lulusan yang mampu bersaing pada taraf internasional 
serta memiliki karakter antara lain memiliki keunggulan dalam bidang kesenian dan olah raga sehingga mampu tampil dan berkompetisi di tingkat nasional dan internasional.

Berdasar visi, misi dan tujuan sekolah tersebut maka SMA Swasta Hosana Medan mencoba untuk memfasilitasi siswa melalui kegiatan ekstrakurikuler pilihan. Kesuksesan seseorang tidak hanya ditentukan oleh kecerdasan intelektual saja (IQ), tetapi kecerdasan emosional (EQ) dan kecerdasan spiritual (SQ) juga sangat berperan untuk membantu siswa dalam upaya meningkatkan prestasi non akademik dengan membekalinya ketrampilan. Walaupun dalam kenyataanya prestasi akademik masih selalu diunggulkan dalam segala hal, dibuktikan dengan adanya Ujian Nasional (UN) yang hanya menilai prestasi akademik saja, tanpa mempertimbangkan kecerdasan yang lain. Keberagaman kecerdasan ini sangat mungkin tidak terakomodasi selama proses pembelajaran, karena selama ini sekolah hanya mengutamakan pencapaian mathematical intelegence dan logika. Padahal potensi anak beragam dan sangat memungkinkan kecerdasan tersebut dapat diasah melalui kegiatan ekstrakurikuler. Petunjuk Teknis Pengembangan Silabus Pendidikan Jasmani dan Olahraga SMA tahun 2004 dijabarkan bahwa : pelajaran pendidikan jasman dan olahraga memiliki fungsi mengembangkan unsur fisik atau motorik, kreativitas dan cita4 rasa estestis siswa dalam berolahraga, mengembangkan etika, kesadaran social dan kesadaran kultural dalam kehidupan bermasyarakat serta rasa cinta terhadap kebudayaan Indonesia. Berdasarkan substansinya, materi pembelajaran pendidikan jasmani dan olahraga meliputi keterampilan teknik, kebugaran jasmani, dan peningkatan unsur fairplay dalam pertandingan.

Kegiatan ekstrakurikuler futsal yang dilaksanakan bertujuan untuk membantu para siswa menggali minat, bakat serta potensi diri. Namun hal ini juga memberikan suatu tujuan agar peserta didik tidak meninggalkan potensi akademiknya di dalam kelas. Kegiatan ekstrakurikuler futsal diharapkan dapat memberikan motivasi terhadap minat dan potensi siswa pada bidang intrakurikulernya di kelas. Pada kegiatan ekstrakurikuler futsal ini siswa diberi bekal keterampilan teknik dalam bermain futsal melalui kegiatan latihan dna pertandingan yang dilakukan baik antar klub maupun antara sekolah. Menurut Tilaar (2004:4) terdapat empat bidang kekuatan gelombang globalisasi yang paling kuat dan menonjol daya dobraknya yaitu bidang iptek, ekonomi, lingkungan hidup dan pendidikan. Bangsa yang cerdas adalah bangsa yang dapat survive di dalam menghadapi berbagai kesulitan. Indonesia dilanda oleh krisis politik, krisis ekonomi, krisis hukum, krisis kebudayaan dan tidak dapat disangkal juga di dalam pendidikan. Salah satu masalah terbesar yang dihadapi dunia pendidikan adalah bagaimana menyesuaikan cara berpikir untuk menghadapi tantangan dunia yang semakin kompleks.

Pengembangan diri merupakan kegiatan yang bertujuan memberikan kesempatan kepada peserta didik untuk mengembangkan dan mengekspresikan diri sesuai dengan kebutuhan, bakat, dan minat setiap peserta didik sesuai dengan kondisi sekolah. Kegiatan pengembangan diri difasilitasi dan atau dibimbing oleh konselor, guru, atau tenaga kependidikan yang dapat dilakukan dalam bentuk kegiatan ekstrakurikuler (Sudibyo, 2006:19). Kegiatan ekstrakurikuler merupakan kegiatan penunjang belajar siswa diluar kegiatan akademiknya di lingkungan sekolah. Kegiatan ekstrakurikuler di sekolah-sekolah menjadi wadah bagi siswa untuk mengembangkan diri mereka dalam meningkatkan kemampuan atau ketrampilan di berbagai bidang sesuai minat dan bakat masing-masing siswa. Kegiatan ini merupakan kegiatan di luar jam sekolah dan merupakan pelajaran tambahan bagi siswa yang bersifat memperdalam, mengulangi dan melatih siswa tentang pengetahuan tertentu. 
Menurut (Usman, 2009:5) manajemen dalam arti luas adalah perencanaan, pengorganisasian, pengarahan, dan pengendalian (P4) sumber daya organisasi untuk mencapai tujuan secara efektif dan efisien. Manajemen dalam arti sempit adalah manajemen yang meliputi: perencanaan program, pelaksanaan program, kepemimpinan, pengawasan atau evaluasi dan system informasi. Manajemen dalam arti luas menurut Sudjana (2004: 18) merupakan serangkaian kegiatan merencanakan, mengorganisasikan, menggerakkan, mengendalikan dan mengembangkan segala upaya dalam mengatur dan14 mendayagunakan sumber daya manusia, sarana, dan prasarana secara efisien dan efektif untuk mencapai tujuan organisasi yang telah ditetapkan. Mengenai konsep manajemen, dapat disimpulkan bahwa manajemen merupakan kegiatan yang diselenggarakan oleh seseorang atau lebih, dalam suatu kelompok, organisasi atau lembaga, untuk mencapai tujuan yang telah ditetapkan dalam organisasi atau lembaga. Dari pengertian manajemen di atas, terdapat tiga dimensi yang sangat krusial yaitu: Pertama dalam manajemen terjadi kegiatan yang dilakukan oleh seorang pengelola (pemimpin, kepala, komandan, ketua dan lain sebagainya) bersama orang lain atau kelompok. Hal ini menunjukkan begitu pentingnya kemampuan dan keterampilan khusus yang perlu dimiliki pengelola untuk melakukan hubungan kemanusiaan dengan orang lain dan untuk mempengaruhi orang lain baik melalui hubungan perorangan maupun melalui hubungan kelompok. Kemampuan dan keterampilan khusus tersebut dapat terlihat pada interaksi antara pihak yang memimpin atau pengelola dan pihak yang dipimpin atau staf atau bawahan. Hubungan kemanusiaan ini terjadi apabila pihak yang memimpin dan yang dipimpin itu terdiri atas kelompok. Kedua, menunjukkan bahwa kegiatan yang dilakukan bersama dan melalui orang lain itu mempunyai tujuan yang akan dicapai. Dimensi ini memberi makna bahwa kegiatan tersebut diarahkan untuk mencapai tujuan yang telah ditetapkan atau disepakati bersama. Ketiga adalah, bahwa pengelolaan itu dilakukan dalam organisasi, sehingga tujuan yang akan dicapai itu merupakan tujuan organisasi. Dengan kata lain tujuan organisasi dicapai melalui kegiatan yang dilakuan bersama orang lain baik perorangan maupun kelompok. Jadi tiga dimensi tersebut meliputi kegiatan melalui dan atau bersama orang lain. Tujuan yang akan dicapai dalam kehidupan organisasi, memerlukan kehadiran pengelola yang memiliki kemampuan dan keterampilan dengan hubungan kemanusiaan untuk mempengaruhi orang-orang lain dalam rangka mencapai tujuan organisasi secara efektif dan efisien.

Pada hakikatnya, SDM terdiri dari daya fikir dan daya fisik setiap manusia, dengan kata lain, terdiri dari jasmani dan rohani. Intinya kemampuan setiap manusia ditentukan oleh daya fikir dan daya fisiknya yang direalisasikan menjadi performance. Hal itu bersifat fleksibel karena dapat di-upgrade, dapat juga ter-downgrade. SDM atau manusia menjadi unsur utama dalam setiap aktivitas yang dilakukan. Peralatan yang handal atau canggih tanpa peran aktif SDM, tidak akan27 berarti apa-apa, karena itu kita dapat mengenal istilah man behind gun. Daya piker adalah kecerdasan yang dibawa lahir (modal dasar) sedangkan kecakapan diperoleh dari usaha (belajar dan pelatihan). Kecerdasan berpatokan pada Intelegence Quotient (IQ) dan Emotion Quality (EQ). Pengertian SDM secara makro adalah penduduk atau warga yang sudah memasuki usia angkatan kerja, baik yang sudah memasuki usia angkatan kerja maupun yang sudah bekerja. Sedangkan pengertian SDM secara mikro adalah orang yang bekerja dan menjadi anggota suatu perusahaan atau institusi yang disebut sebagai karyawan, pegawai, buruh, pekerja, tenaga kerja, dan lain sebagainya. Beranjak dari pengertian tersebut, lebih dalam lagi bahwa SDM adalah orang yang bekerja sebagai motor penggerak pada suatu perusahaan dan berfungsi sebagai aset perusahaan atau institusi yang 
diperhitungkan dan perlu dikembangkan lagi kemampuan hardskill serta softskill-nya. Menurut (Subroto, 2009:67) kegiatan Ekstrakurikuler adalah kegiatan kurikuler yang dilakukan oleh peserta didik di luar jam belajar kegiatan intrakurikuler dan kegiatan kokurikuler, di bawah bimbingan dan pengawasan satuan pendidikan. Kegiatan Ekstrakurikuler diselenggarakan dengan tujuan untuk mengembangkan potensi, bakat, minat, kemampuan, kepribadian, kerjasama, dan kemandirian peserta didik secara optimal dalam rangka mendukung pencapaian tujuan pendidikan nasional.

Olahraga Futsal adalah olahraga sepakbola dalam ruangan dengan kompetensi kemampuan teknik tinggi, dengan pemain sedikit waktu bermain cepat dan kesempatan mencetak skor lebih besar. Futsal memiliki unsur gerak dinamis yaitu pemainnya dituntut untuk selalu bergerak dan dibutuhkan keterampilan teknik yang baik serta mempunyai determinasi yang tinggi (Pohny, Budiman, \& Ginanjar, 2017). Kegiatan ekstrakurikuler selama ini hanya dipahami sebagai kegiatan sampingan diluar jam pembelajaran sekolah, masih banyak sekolah yang belummengelola kegiatan ekstrakurikulernya dengan sungguh sungguh, sehingga dari kegiatan ekstrakurikuler hanya menghasilkan nilai ekstra yang dituangkan dalam rapot saja. Prestasi selama ini dipahami sebagai kemampuan intelektual, sebatas perolehan nilai akademik yang diukur dengan tes mata pelajaran tertentu. Berkaitan dengan pengelolaan kegiatan ekstrakurikuler, manajemen yang baik memegang peranan yang sangat penting dalam proses untuk mencapai suatu prestasi.

Dengan manajemen yang tepat meliputi perencanaan, pengorganisasian, pelaksanaan, pengawasan, dan evaluasi serta dukungan dari semua warga sekolah juga sarana pendukung lain, kegiatan ekstrakurikuler jika dikelola dengan sungguh-sungguh akan mampu mencapai prestasi non akademik. Pengelolaan ekstrakurikuler futsal di SMA Swasta Hosana Medan akan dapat mencapai prestasi jika melaksanakan fungsi manajemen dalam pengelolaan sumber daya manusia (siswa) dan proses regenerasinya.

Ektrakurikuler di SMA Swasta Hosana Medan terdiri dari berbagai macam yang salah satunya adalah ektrakurikuler buluangkis, seni dan keterampilan38 prestasi yang menjadi ekstrakurikuler Futsal. Untuk meningkatkan peran ektrakurikuler di sekolah, maka ektrakurikuler futsal harus dikelola dengan tepat untuk kemajuan sekolah. Pengelolaan ekstrakurikuler futsal di SMA Swasta Hosana Medan dilakukan dengan perencanaan, pengorganisasian, pelaksanaan, dan pengawasan terkait dengan sumber daya manusia, proses regenerasi, dan anggaran yang kemudian aspek seluruhnya dapat mewakili dari perkembangan ektrakurikuler dalam mengembangkan dan meningkatkan prestasi non akademik.

\section{METODE PENELITIAN}

Penelitian ini menggunakan metode kualitatif dengan pendekatan studi kasus. Pendekatan studi kasus merupakan strategi penelitian di mana di dalamnya peneliti menyelidiki secara cermat suatu peristiwa, aktivitas, proses, program atau sekelompok individu. Kasus-kasus dibatasi oleh waktu dan aktivitas, peneliti mengumpulkan informasi secara lengkap dengan menggunakan berbagai prosedur pengumpulan data berdasarkan waktu yang telah ditentukan (Creswell, 2014:20). Sedangkan menurut (Bungin \& M.Burhan, 2007:68) desain deskriptif kualitatif bertujuan untuk menggambarkan, meringkaskan berbagai kondisi, berbagai situasi, atau berbagai fenomena realitas sosial yang ada di masyarakat yang menjadi objek penelitian, dan berupaya menarik kesimpulan itu ke permukaan sebagai suatu ciri, karakter, model, tanda, atau gambaran tentang kondisi, 
situasi, maupun fenomena tertentu. Hal ini senada dengan yang dikemukakan Bogdan and Taylor dalam (Moleong, 2007:3) mendefinisikan metodologi kualitatif sebagai prosedur penelitian yang menghasilkan data deskriptif berupa kata-kata tertulis atau lisan dari orangorang dan perilaku yang diamati. Pendekatan studi kasus adalah untuk memusatkan diri pada suatu unit tertentu dari berbagai fenomena mengenai pengelolaan ekstrakurikuler futsal baruklinting dan memfokuskan perhatian pada studi tindakan manusia sebagai 3940 instrumen penelitian utama (Mulyono, 2008:3). Peneliti hendaknya mampu memberikan pertanyaan yang jitu, menguasai masalah yang diteliti, menentukan unit-unit analisis terlebih dahulu dengan jelas, mampu bersikap netral dan objektif, adalah kriteria untuk menginterpretasikan temuan (Bungin, 2007:232).

Pendekatan studi kasus digunakan untuk mempertahankan keutuhan dari objek, artinya data yang dikumpulkan dalam rangka studi kasus dipelajari sebagai suatu keseluruhan yang terintegrasi, karena fokus penelitiaannya hanya diarahkan pada pelaksanaan pengelolaan ekstrakurikuler futsal yang dilaksanakan di SMA Swasta Hosana Medan. Penelitian ini menggunakan metode deskriptif kualitatif dengan pendekatan studi kasus, dengan alasan (1) dengan asumsi bahwa masalah yang akan diteliti lebih tepat menggunakan metode deskriptif kualitatif dengan pendekatan studi kasus, (2) dengan metode penelitian ini dapat dikumpulkan data dari seluruh komponen yang mendukung Pengelolaan Ekstrakurikuler Futsal di SMA Swasta Hosana Medan. Tahapan dalam penelitian ini terdiri dari kegiatan : 1) pengumpulan data terkait kajian-kajian yang terdapat pada jurnal penelitian yang meliputi "Pengelolaan ekstrakurikuler" dan "ekstrakurikuler Futsal SMA"; 2) melakukan analisis terhadap pengelolaan ekstrakurikuler ; 3) melakukan analisis hubungan terhadap pengelolaan ekstrakurikuler dan ekstrakurikuler futsal tingkat SMA; dan 4) menemukan kesimpulan dari studi analisis. Dalam penelitian kualitatif, di dalamnya peneliti terlibat dalam pengalaman yang berkelanjutan dan terus-menerus dengan para informan. Keterlibatan inilah yang nantinya memunculkan serangkaian isu-isu strategis, etis dan personal dalam penelitian kualitatif (Bungin \& M.Burhan, 2007:65). Peran peneliti menentukan penjelasan tentang masalah-masalah yang mungkin muncul dalam proses pengumpulan data. Langkah-langkah pengumpulan data meliputi usaha membatasi penelitian, mengumpulkan informasi melalui angket, dokumentasi, materi-materi visual, serta merancang protokol untuk merekam/ mencatat informasi. Peneliti mengumpulkan beragam jenis data dan42 memanfaatkan waktu seefektif mungkin untuk mengumpulkan informasi di lokasi penelitian

\section{HASIL DAN PEMBAHASAN}

Analisis pada kajian pengeloaan ekstrakurikuler merupakan rangkaian kegiatan yang memiliki kegunaan untuk meningkatkan dan menumbuhkan minat pada ektsrakurikuler. Pelaksanaan ekstrakurikuler memiliki rencana startegis yang terdiri dari kegiatan :

1) Perencanaan.

Kegiatan perencanana merupakan aktivitas menyusun program atau kegiatan yang memiliki tujuan untuk pembentukkan sistem ekstrakurikuler.

2) Pengorganisasian59

Rangkaian pengorganisasian dilakukan dengan menetapkan salh satu orang dalam kelompok untuk membantuk ketetapan program ekstrakuirkuler. Dengan diadakannya peraturan untuk anggota ekstrakurikuler dapat mentaati peraturan tersebut dan 
melaksanakan kegiatan ekstrakurikuler dengan baik. Menetapkan penanggung jawab dalam kegiatan ekstrakurikuler ini adalah Kepala Sekolah sebagai penanggung jawab maupun penasehat, Wakil Kepala Sekolah Bagian Kesiswaan, pembina kegiatan ekstrakurikuler broadcasting dan juga pengurus serta anggota.

3) Pelaksanaan

Pelaksanaan merupakan langkah ketiga setelah kegiatan perencanaan dan pengorganisasian. Pelaksanaan merupakan suatu implementasi dari perencanaan dan pengorganisasian. Pada pelaksanaan ini yang pertama dilakukan yaitu waktu pelaksanaan kegiatan ekstrakurikuler. Kegiatan ekstrakurikuler ini mempunyai

alokasi waktu yang sudah direncanakan sebelumnya dalam pelaksanaan supaya tidak menganggu jam pelajaran.

4) Evaluasi

Evaluasi dalam setiap organisasi sangatlah penting dan berpengaruh dalam kedepannya lebih baik lagi. Evaluasi yang baik dilakukan dengan jangka waktu panjang maupun pendek untuk menilai kinerja setiap individu maupun program keseluruhan dalam orgnanisasi yang dikerjakan. Di lakukannya evaluasi bertujuan untuk membuat organisasi lebih baik lagi. Untuk aspek yang dievaluasi yakni hambatan. Setiap organisasi dalam pelaksanaan kegiatan selalu ada setiap kendala atau hambatan. Peran dalam evaluasi dalam organisasi sangatlah berpengaruh untuk organisasi lebih baik. Untuk peran dalam pelaksanaaan evaluasi juga bisa mengharapkan memberikan masukan yang baik untuk kemajuan suatu organisasi tersebut. Dengan hal tersebut yang menjadi peran dalan kegiatan ekstrakurikuler yaitu Kepala Sekolah, Wakil Kepala Bagian Kesiswaan, Pembina dan juga Ketua ekstrakurikuler. Untuk program kerja yang mengevaluasi yaitu pembina dan juga angota-anggota.

5) Pengembangan

Ekstrakurikuler tidak luput juga memiliki sifat pengembangan terhadap peserta didik yang mengikuti. Sifat peserta didik ini sangat berpengaruh juga untuk mencapai hasil atau prestasi yang baik. Ekstrakurikuler tidak luput juga memiliki sifat kreatif terhadap peserta didik yang mengikuti. Sifat peserta didik ini sangat berpengaruh juga untuk mencapai hasil atau prestasi yang baik. Kegiatan Ekstrakurikuler perkembangan sistem aktivitas seseorang dalam satuan pendidikan, yang memiliki tujuan untuk perkembangan sifat kreatif terhadap peserta didik yang mengikuti. Sifat peserta didik ini sangat berpengaruh juga untuk mencapai hasil atau prestasi yang baik.

Cabang Olahraga futsal merupakan aktivitas fisik yang dilakukan secara tim atau kelompok dengan menggunakan bola sebagai objek untuk diperebutkan atau diatur sedemikian rupa sehingga mencapai tujuan permainan. Futsal dilakukandengan teknik games antara dua tim yang berjumlah 6 orang yang terdiri dari penjaga gawang, pemain bertahan, pemain tengah, dan pemain menyerang. Area permainan futsal adalah lapangan mini sepak bola yang berukuran panjang 25-42 meter dan lebar 15-25 meter.

Olahraga Futsal pada tingkat SMA memiliki banyak peminat mulai dari pria hingga wanita, serta dari berbagai usia. Penerapan olahraga futsal merupakan kegiatan diluar kegiatan belajar di kelas dan bukan termasuk materi Pendidikan Jasmani Olahraga dan Kesehatan (PJOK). Implementasi futsal tingkat SMA merupakan peningkatan kemampuan skil siswa berupa teknik, fisik, dan taktik permainan sehingga terciptanya kemampuan siswa dalam melakukan pertandingan. Ekstrakurikuler futsal untuk siswa SMA dikembangkan sebagai sarana dan fasilitas pelayanan sekolah dalam memberikan wadah minat dan bakat 
siswa sehingga akan terbentuk kebiasaan siswa untuk melalukan olahraga. Ekstrakurikuler futsal juga menjadi stimulus daya tarik siswa untuk mengikuti kegiatan, sehingga akan membantu pengisian waktu luang siswa dan terhindar dari kegiatan yang tidak terkontrol atau di luar kegiatan sekolah

Analisis terhadap kajian pengelolaan ekstrakurikuler dan kajian ekstrakurikuler futsal siswa tingkat SMA dapat dirumuskan dan kemudian direkomendasikan kepada Sekolah SMA Hosana Medan. Hasil analisis kajian pengelolaan ekstrakurikuler diperoleh karakteristik bahwa setiap penerapan62 manajemen atau pengelolaan suatu kegiatan (ekstrakurikuler) dapat dilakukan dengan proses : (1) Perencanaan, Kegiatan perencanana merupakan aktivitas Menyusun program atau kegiatan yang memiliki tujuan untuk pembentukkan system ekstrakurikuler; (2) Pengorganisasian, Rangkaian pengorganisasian dilakukan dengan menetapkan salah satu orang dalam kelompok untuk membantuk ketetapan program ekstrakuirkuler. Dengan diadakannya peraturan untuk anggota ekstrakurikuler dapat mentaati peraturan tersebut dan melaksanakan kegiatan ekstrakurikuler dengan baik; (3) Pelaksanaan, Pelaksanaan merupakan Langkah ketiga setelah kegiatan perencanaan dan pengorganisasian. Pelaksanaan merupakan suatu implementasi dari perencanaan dan pengorganisasian. Pada pelaksanaan ini yang pertama dilakukan yaitu waktu pelaksanaan kegiatan ekstrakurikuler. Kegiatan ekstrakurikuler ini mempunyai alokasi waktu yang sudah direncanakan sebelumnya dalam pelaksanaan supaya tidak menganggu jam pelajaran; (4) Evaluasi, Evaluasi dalam setiap organisasi sangatlah penting dan berpengaruh dalam kedepannya lebih baik lagi. Evaluasi yang baik dilakukan dengan jangka waktu panjang maupun pendek untuk menilai kinerja setiap individu maupun program keseluruhan dalam orgnanisasi yang dikerjakan. Di lakukannya evaluasi bertujuan untuk membua organisasi lebih baik lagi. Untuk aspek yang dievaluasi yakni hambatan. Setiap organisasi dalam pelaksanaan kegiatan selalu ada setiap kendala atau hambatan; dan (5) Pengembangan, Ekstrakurikuler tidak luput juga memiliki sifat kreatif untuk mengembangkan terhadap peserta didik yang mengikuti. Sifat peserta didik ini sangat berpengaruh juga untuk mencapai hasil atau prestasi yang baik. Ekstrakurikuler tidak63 luput juga memiliki sifat kreatif terhadap peserta didik yang mengikuti. Sifat peserta didik ini sangat berpengaruh juga untuk mencapai hasil atau prestasi yang baik.

Hasil kajian pada aspek Esktrakurikuler futsal tingkat SMA adalah peminatan kegiatan diluar kelas sebagai sarana pemandu bakat dan pengisi waktu luang. Implementasi futsal tingkat SMA merupakan peningkatan kemampuan skil siswa berupa teknik, fisik, dan taktik permainan sehingga terciptanya kemampuan siswa dalam melakukan pertandingan. Ekstrakurikuler futsal untuk siswa SMA dikembangkan sebagai sarana dan fasilitas pelayanan sekolah dalam memberikan wadah minat dan bakat siswa sehingga akan terbentuk kebiasaan siswa untuk melalukan olahraga. Ekstrakurikuler futsal juga menjadi stimulus daya tarik siswa untuk mengikuti kegiatan, sehingga akan membantu pengisian waktu luang siswa dan terhindar dari kegiatan yang tidak terkontrol atau diluar kegiatan sekolah. Jika dikaitkan hasil kajian pengelolaan dan ekstrakurikuler futsal dapat dihasilkan perpaduan bahwa pada kegiatan pemanduan bakat siswa SMA pada bidang olahraga futsal, maka sangat diperlukan kepengurusan untuk mewadahi aktivitas siswa. Kepengurusan dimaksud adalah pembentukkan sistem organisasi sebagai sistem koordinasi antara siswa dan sekolah, siswa dan tim, serta mampu meningkatkan prestasi di luar akademik. Pembentukkan sistem organisasi meliputi beberapa sistem kerja yaitu (1) Perencanaan 
dengan menetapkan sistem rekrutmen siswa dan program latihan siswa yang mengikuti ekstrakurikuler futsal; (2) Pengorganisasian dengan membentuk64 struktur kepengurusan yang terdiri dari ketua, sekretaris, bendahara, dan bidang yang dibutuhkan; (3) Pelaksanaan yang dilakukan dengan menjalankan program kerja yang telah dirumuskan dan memiliki pengaruh pada peningkatan prestasi siswa dan keunggulan sekolah; (4) Evaluasi yang dilakukan dengan cara menilai danmemperbaiki setiap kegiatan yang telah dilakukan sebagai dasar perencanan baru pada kegiatan atau program yang akan direncanakan kedepan; dan (5) Pengembangan merupakan hasil dari evaluasi yang bertujuan untuk meningkatan peran dan fungsi dari ektrakurikuler futsal di sekolah dengan mengikitsertakan dewan guru dan kepala sekolah sebagai dewan pembina dan pengawah.

Berdasarkan hasil analisis di atas, maka dapat direkomendasikan kepada Sekolah Menengah Atas (SMA) Swasta Hosana Medan untuk menerapkan system pengelolaan pada ekstrakurikuler futsal sebagai wujud peningkatan peran di lingkungan sekolah. Sistem pengelolaan yang telah dirumuskan terdiri dari perencanaan, pengorganisasian, pelaksanaan, evaluasi, dan Pengembangan merupakan sarana melatih sekolah untuk menciptakan kemandirian siswa dalam mengelola suatu wadah belajar dan pengembangan diri.

\section{KESIMPULAN}

Penelitian Analisis terhadap kajian pengelolaan ekstrakurikuler dan kajian ekstrakurikuler futsal siswa tingkat SMA dapat dirumuskan dan kemudian direkomendasikan kepada Sekolah SMA Hosana Medan pada masa Pendemi Corona Virus Desease-19 dilakukan dengan studi pustaka jurnal nasional. Kajian dilakukan dengan menemukan karakteristik konsep pengelolaan ekstrakurikuler dan karakteristik ektrakurikuler futsal di skeolah tingkat SMA. Analisis kajian pengelolaan ekstrakurikuler diperoleh karakteristik bahwa setiap penerapan manajemen atau pengelolaan suatu kegiatan (ekstrakurikuler) dapat dilakukan dengan proses perencanaan, pengorganisasian, pelaksanaan, evaluasi, dan pengembangan. Analisis kajian ekstrakurikuler futsal adalah peminatan kegiatan diluar kelas sebagai sarana pemandu bakat dan pengisi waktu luang. Implementasi futsal tingkat SMA merupakan peningkatan kemampuan skil siswa berupa teknik, fisik, dan taktik permainan sehingga terciptanya kemampuan siswa dalam melakukan pertandingan. Pembentukkan sistem organisasi meliputi beberapa sistem kerja yaitu (1) Perencanaan dengan menetapkan sistem rekrutmen siswa dan program latihan siswa yang mengikuti ekstrakurikuler futsal; (2) Pengorganisasian dengan membentuk struktur kepengurusan yang terdiri dari ketua, sekretaris, bendahara, dan bidang yang dibutuhkan; (3) Pelaksanaan yang dilakukan dengan menjalankan program kerja yang telah dirumuskan dan memiliki pengaruh pada peningkatan prestasi siswa dan keunggulan sekolah; (4) Evaluasi yang dilakukan dengan cara menilai dan memperbaiki setiap kegiatan yang telah dilakukan sebagai dasar perencanan baru pada kegiatan atau program yang akan direncanakan kedepan; dan (5) Pengembangan merupakan hasil dari evaluasi yang bertujuan untuk meningkatan peran dan fungsi dari ektrakurikuler futsal di sekolah dengan mengikitsertakan dewan guru dan kepala sekolah sebagai dewan pembina dan pengawah.

Berdasarkan hasil analisis di atas, maka dapat direkomendasikan kepada Sekolah Menengah Atas (SMA) Swasta Hosana Medan untuk menerapkan system pengelolaan pada 
ekstrakurikuler futsal sebagai wujud peningkatan peran di lingkungan sekolah. Sistem pengelolaan yang telah dirumuskan terdiri dari perencanaan, pengorganisasian, pelaksanaan, evaluasi, dan Pengembangan merupakan sarana melatih sekolah untuk menciptakan kemandirian siswa dalam mengelola suatu wadah belajar dan pengembangan diri.

\section{DAFTAR PUSTAKA}

Aditya, R., \& Azandi, F. (2020). Effect of Play Approach Against Learning Outcomes in Soccer Games. JPJ (Jurnal Pendidikan Jasmani), 1(1), 1-7.

Bungin, \& M.Burhan. (2007). Penelitian Kualitatif, Komunikasi, Ekonomi, Kebijakan Publik dan Ilmu Sosial. Jakarta: Kencana Prenada Media Group.

Creswell, J. W. (2014). Research Design Pendekatan Kualitatif, Kuantitatif, dan Mixed. Terjemahan:Achmad Fawaid. Yogyakarta: Pustaka Pelajar.

David, R. F. (2004). Konsep Manajemen Strategis, Edisi VII (terjemahan). Jakarta: PT Indeks. Depdiknas. (2006). Standar Kompetensi Dasar Seni Budaya dan Keterampilan. Jakarta: Depdiknas.

Engkoswara, \& Komariah. (2010). Paradigma Manajemen Pendidikan Menyongsong Otonomi Daerah. Bandung: Yayasan Amal Keluarga.

Hamalik, O. (2009). Kurikulum dan Pembelajaran. Jakarta: Bumi Aksara.

Hasibuan, S. P. M. (2005). Manajemen Sumber Daya Manusia, cetakan II. Jakarta: PT Gunung Agung.

Hikmat. (2011). Manajemen Pendidikan. Bandung: Pustaka Setia.

Moleong, J. L. (2007). Metodologi Penelitian. Bandung: PT. Remaja Rosda Karya.

Mulyono. (2008). Manajemen dan Administrasi Pendidikan. Jakarta: Rhineka Cipta.

Pidarta, M. (2011). Manajemen Pendidikan Indonesia. Jakarta: PT.Rhineka Cipta.

Siswanto. (2007). Pengantar Manajemen. Jakarta: Bumi Aksara.

Subroto, B. S. (2009). Proses Belajar Mengajar di Sekolah. Jakarta: Rineka Cipta.

Sudjana, D. (2004). Manajemen Program Pendidikan: Untuk Pendidikan Nonformal dan Pengembangan Sumber Daya Manusia. Bandung: Falah Production.

Sugiyono. (2014). Metode Penelitian Pendidikan Pendekatan Kuantitatif, Kualitatif, dan R\&D. Bandung: Alfabeta. 
Taufik, R. (2015). Manajemen Kegiatan Ekstrakurikuler Barbasis Pengembangan Karakter Siswa. Manajer Pendidikan, 9(4).

Terry, \& George.R. (2009). Prinsip-prinsip Manajemen. Jakarta: Bumi Aksara.

Usman, E. (2009). Evaluasi Implementasi Manajemen. Jakarta: Universitas Pendidikan Indonesia. 